\title{
Peertechz
}

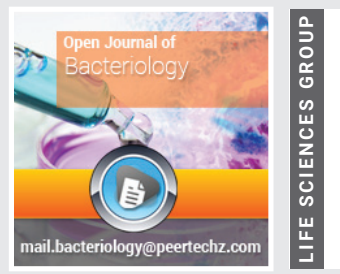

\section{Purulent pleurisy in children}

\section{Mouad Fatima Zahra ${ }^{1 *}$, Elmoussaoui $\mathbf{S}^{1}$, Elfakiri $\mathbf{K}^{1}$, Rada N${ }^{1}$, Draiss $\mathbf{G}^{1}$, Soraa $\mathbf{N}^{2}$ and Bouskraoui $\mathbf{M}^{1}$}

'Department of Pediatrics, Mohammed VI University Medical Center Marrakesh, Morocco

${ }^{2}$ Department of Microbiology, Mohammed VI University Medical Center Marrakesh, Morocco

Received: 10 Septembet, 2020

Accepted: 30 Septembet, 2020

Published: 01 October, 2020

*Corresponding author: Mouad fatima Zahra, Department of Pediatrics, Mohammed VI University Medical Center Marrakesh, Morocco, E-mail: fzmouad@otmail.fr

Keywords: Empyema; Complications; Children; Antibiotics; Morocco

https://www.peertechz.com

\section{Summary}

Introduction: The incidence of purulent pleurisy is on the rise in several series in the literature. It is a significant cause of morbidity in pediatrics. The main objective of our study is to analyze the epidemiological characteristics and the prognosis of purulent pleurisy of the child.

Material and methods: We conducted an 11-year retrospective study (2008-2019), including 74 children with documented pleurisy, who were hospitalized in the Department of Pediatrics A of the Mohammed VI University Medical Center in Marrakesh.

Results: Purulent pleurisy accounts for $0.5 \%$ of pathologies in children. The average age was 4.5 years, with a male predominance (70\% of boys). The average time before consultation was 15 days. Respiratory symptoms were cough ( $82 \%)$, chest pain (41\%), and dyspnea (29\%). Clinical examination revealed fluid effusion syndrome (97\%). On chest X-ray, the effusion was often unilateral (95\%), of average or large abundance (48\% and $46 \%$ respectively). Thoracocentesis for diagnostic and therapeutic purposes was performed in $84 \%$ of cases. Surgery for complicated pleurisy or drainage failure was reported in $20 \%$ of patients.

Conclusions: Pneumococcus and Staphylococcus aureus remain the main germs of the child's purulent pleurisy. Thanks to the exclusive use of chest drainage associated with antibiotic therapy, the prognosis of our patients is satisfactory.

\section{Introduction}

Purulent pleurisy or empyema is a frequent reason for hospitalization, and is characterized by serious morbidity. In the last few years, there has been an increase in pleurisies in a number of countries $[1,2]$. This recrudescence could be due in part to the virulence and resistance of bacteria to antibiotics, and to factors related to the host which are essentially young age, malnutrition, immunodepression and an insufficient vaccine coverage against major pleurisy-causing germs [3]. The morbidity could be linked to a long duration of hospitalization and frequent medical procedures. These facts notwithstanding, there is no consensus, in the present time, on the management of pleurisy, because no one method has proven superior to others. We seek therefore by the present study to take stock of the epidemiological, clinical, paraclinical, therapeutic and evolutional aspects of this condition in children aged 0 to 15 years admitted in the Mohammed VI University Medical Center in Marrakesh so as to propose measures to improve management.

\section{Material and methods}

Our study is a retrospective, descriptive and analytic study spanning the period from January 2008 to April 2019 conducted in the Department of Pediatrics A of the Mother-Child Hospital of the Mohammed VI University Medical Center in Marrakesh. Medical files of all children aged less than 15 years hospitalized for pleurisy were retained. For each patient we gathered the age, sex, origin, duration of symptoms, radiologic and lab data, analysis of the extracted fluid, medical as well as surgical management, and outcomes.

\section{Results}

\section{Epidemiological data}

We retained 74 cases of purulent pleurisy over a period of 11 years. During this period 14022 children were hospitalized, representing a frequency of $0.5 \%$.

The ages of our patients ranged from 6 months to 15 years with a mean of 4 and $1 / 2$ years. Children aged 5 to 15 years were most represented with a total of 37 cases (50\%) Table 1.

We remarked a total of 52 male patients $(70 \%)$ versus 22 female patients $(30 \%)$. The majority of patients $(90 \%)$ were up to date on the national vaccination schedule. The cumulative 
distribution of pleurisies over a period of 11 years showed a mean case per year of 6 . We also noted a recrudescence of cases during the month of October to March corresponding to the cold season. During this period, we recorded $63.5 \%$ the cases as shown in Figure 1. Approximately $62.1 \%(\mathrm{~N}=46)$ of patients came from rural zones.

The chief complaints of patients were dominated by fever, cough, chest pain and difficulty breathing, and respectively represented: 68 cases (92\%), 61 cases $(82 \%), 30$ cases $(41 \%)$ and 22 cases $(29 \%)$ as shown in Table 2 . We also recorded digestive presentations (diarrhea and vomiting) in $15 \%$ of cases.

The mean duration of evolution of symptoms before hospitalization was 15 days with extremes of 1 and 30 days. Before hospitalization, $20 \%$ of patients were already on antibiotics, $16 \%$ had already received unspecified treatments.

Constitutional symptoms found on admission were fever $(60 \%)$, and a general feeling of unwellness ( $40 \%)$. Physical signs upon examination were dominated by signs of pleural effusion (97\%), and respiratory distress (67.5\%) as shown in the Table 3.

\section{Paraclinical aspects}

Chest X-ray done systematically in children upon admission revealed pleurisy, usually unilateral (94\%), of average or large volume (respectively $48 \%$ and $46 \%$ ).

Complete blood count (CBC) showed hyperleucocytosis in $70 \%$ of cases with a predominance of polynuclear neutrophiles in $68 \%$ of cases, and anemia in $70 \%$ of cases.

Thoracocentesis was performed in 63 patients in our study, that is in $84 \%$ of cases, and was unsuccessful in 3 cases.

The examination of the fluid includes a macroscopic, cytological, biochemical and bacteriological analysis: the macrocopic appearance was purulent in $73 \%$ of cases, or 46 patients (Figure 2).

Table 1: Age distribution of patients.

\begin{tabular}{|c|c|c|}
\hline Age groups (month) & Number of cases & Percentage \\
\hline Less than 3 months & 2 & 2.7 \\
\hline 3 to 23 months & 15 & 20.3 \\
\hline 24 to 59 months & 20 & 27 \\
\hline $60-180$ months & 37 & 50 \\
\hline Total & 74 & 100 \\
\hline
\end{tabular}

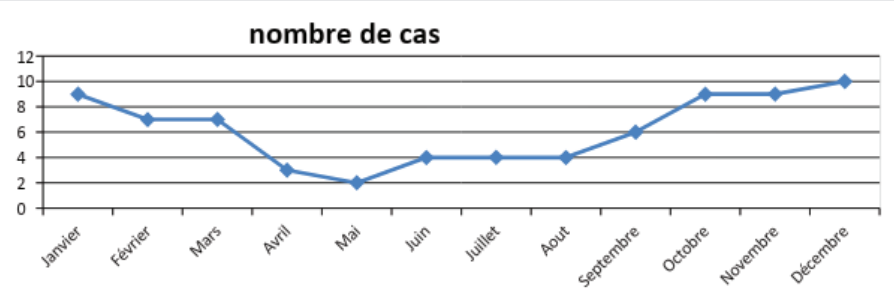

Figure 1: Distribution of cases according to months.
Table 2: Chief complaints as reported by patients.

\begin{tabular}{|c|c|c|}
\hline Chief complaint & Number of cases & Percentage \\
\hline Fever & 68 & 92 \\
\hline Cough & 61 & 82 \\
\hline Chest pain & 30 & 41 \\
\hline Dyspnea & 22 & 29 \\
\hline Abdominal pain & 2 & 1.48 \\
\hline
\end{tabular}

Table 3: Frequency of anomalies on physical examination.

Physical signs

Number of cases Percentages

Pleural effusion syndrome

97

Lung condensation syndrome

2

2.7

Mixed pleural effusion syndrome

3

\subsection{5}

Rhonchi

8

Crackles

10

10.8

Wheezes

Respiratory distress

(polypnea + signs of difficulty breathing)

\section{1}

Chest wall anomalies*

50

*: (scorch scars inflicted by traditional healers, right para vertebral mass, scoliotic posture, pain on palpation of left hemithorax)

\section{Macroscopic aspects of pleural fluid}

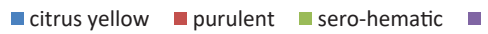

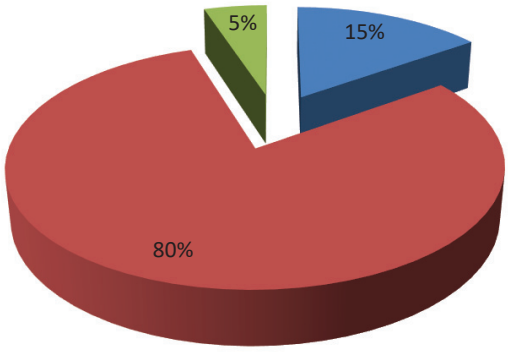

Figure 2: Macroscopic aspects of pleural fluid.

60 samples from the 63 pleural punctures performed showed a protein level greater than or equal to $30 \mathrm{~g} / \mathrm{l}$ with an average of $50.2 \mathrm{~g} / \mathrm{l}$. - the rest of the biochemical study: determination of pleural glucose, $\mathrm{pH}$ and Lactate dehydrogenase (LDH) was not done.

The cytological study of pleural fluid showed in the majority of cases an increase in the number of white blood cells and a predominance of altered polynuclear neutrophils with an average of 30,132 elements / $\mathrm{mm}^{3}$ ( $78 \%$ on average).

Bacteriology of the extracted fluid was positive in 45 cases with a predominance of Streptococcus pneumoniae (22\%), followed by Staphylococcus aureus (18\%), Streptococcus spp (16\%), Enterococcus spp (6\%) and coagulase negative Staphylococcus (3\%). Enterobacteria were isolated in $15 \%$ of strains, and Pseudomonas aeroginosa was isolated in $4 \%$ of cases (Figure 3 ).

Antibiotic sentivity assays showed sentivity to penicillin in 
$68.75 \%$ of Streptococcus pneumoniae. All Staphylococcus aureus strains were sensitive to meticilline. Among enterobacteria, resistance to third generation cephalosporin was $35 \%$. No strain was shown to be multi resistant in the isolations of Pseudomonas aeroginosa.

\section{Therapeutic aspects}

The management consisted in a presumptive broadspectrum antibiotics acting on both aerobics and anaerobics. Patients were started on treatment before lab results were acquired, with eventual adjustment of treatment based on results. Patients also underwent thoracocentesis (84\%), thoracostomy drainage $(20 \%)$, decortication in case of pachypleuritis $(2.96 \%)$, analgesics/antipyretics (90\%), and received $\mathrm{O}_{2}$ in case of respiratory distress (37.5\%). Physiotherapy was systematic. The most frequently used antibiotics were amoxicilline + clavulanic acid (70\%), ceftriaxone (35\%), gentamicin $(20 \%)$, and metronidazole $(4 \%)$.

\section{Evolutional aspects}

The mean duration of hospitalization was 17.17 days, and ranged from 3 to 30 days. Outcomes were satisfactory in 65 patients $(87.83 \%)$, and unsatisfactory in 9 patients $(12.16 \%)$, 5 of the latter presenting with sequellae such as pachypleuritis $(6.7 \%)$, and pneumothorax in 4 patients following accidental removal of the drain $(5.4 \%)$.

There was no case of hospital mortality in our study Figure 4

\section{bacteriological profile of purulent pleurisy}
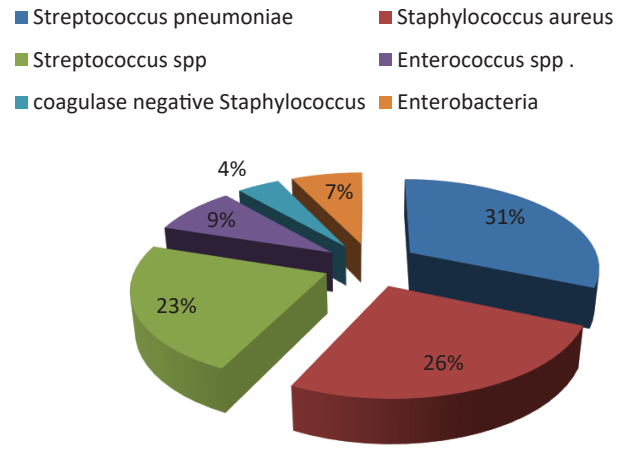

Figure 3: Bacteriological profile of purulent pleurisy

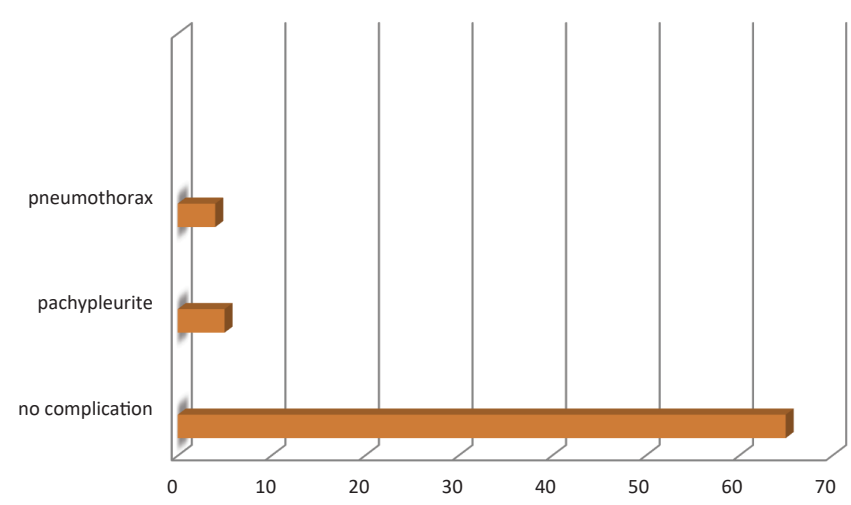

Figure 4: Evolutional profile of cases.

\section{Discussion}

Purulent pleurisy is defined by the presence of purulent effusion between the two folds of the pleura. This fluid is characterized by its thickness and cream-like appearance with the presence of altered polynuclear cells [1]

\section{Epidemiological aspects}

The incidence of purulent pleurisies is in continuous increase in the world. According to a study conducted in Scotland, the incidence of pleurisies increased from 1/100000 in 1998 to 3.7/100000 in 2005 [4]. This recrudescence could be due not only to the antibiotic resistance of germs, but also intrinsic factors of hosts, such as malnutrition, immunodepression and young age [3]. However, it must be admitted that despite the large numbers of publications on the subject, so much remains unanswered for the clinician. In our study, we noted an increase of cases of pleurisy hospitalized in our department since January 2008 to April 2019.

The male predominance in our study was in line with reports by Praveen S Bagalkot, et al. [5], D Narayanappa, et al. [6] FZ Khouchilia, et al. [7]. The mean age of our patients was 4.5 years. The same trend was reported by Koueta [8] and Joonho [9] (5.75 years). According to Roxanne, et al. [10], however, anti-pneumococcal vaccination seemed to decrease the mean age of occurrence of the disease (2.1 years). We remarked that toddlers were the most affected by pleurisies. This observation was corroborated by results of several authors [8].

The influence of season was observed in our study, $(67.5 \%)$ as was signaled by Zeriouel (68.6\%). This observation reinforces the hypothesis that viral co-infection could be one cause of the increase in the incidence of infectious pleurisies in children. The same observation was reported by Baranwal, Rashna et Koueta $[8,11,12]$. However, in the Indian studies $[11,12]$, the greatest numbers of cases were observed during the hot and humid periods in July, August and September.

\section{Clinical aspects}

The mean duration of evolution of symptoms before hospitalization was 15 days in our series. This delay, though variable, was also found by several other African authors $[8,13,14]$. This could be explained by the challenge of geographical accessibility, limited financial means and the high rate of self-medication.

Fever was the most frequent chief complaint (92\%) and was associated with cough (82\%), chest pain $(41 \%)$ and dyspnea (29\%), as well as digestive manifestations (15\%) such as diarrhea and vomiting. Similar findings were made by WeilOlivier, et al. [15].

The main clinical signs observed in our study were mostly respiratory: pleuretic syndrome (97\%) and respiratory distress $(67.5 \%)$ were identical to those reported in the literature [1618 . 


\section{Paraclinical aspects}

We noted $46 \%$ of large volume pleurisy [18]. The abundance of pleural effusion could be explained by the delay in consulting, and therefore a delay in diagnosis and management. The fluid drawn was positive in 45 cases for germs: Streptococcus pneumoniae (22\%), followed by Staphylococcus aureus (18\%), Streptococcus spp (16\%), Enterococcus spp (6\%) and coagulase negative Staphylococcus (3\%). Enterobacteria were isolated in $15 \%$ of strains and Pseudomonas aeroginosa was isolated in $4 \%$ of cases. Our findings are similar to those by Thiami L, et al. [2] and Garba M [19]. However, recent studies in India revealed Staphylococcus aureus to be the lead cause of purulent pleurisies in children [20-22]. According to a French study, among 239 observations of pleurisy collected in 67 pediatrics hospitals, a germ was found in $36 \%$ of cases. Pneumococcus alone represented $80 \%$ of isolates, and streptococcus and staphylococcus were the least frequent (10 and $6 \%$ respectively) [11]. A retrospective study of 128 cases of purulent pleurisy collected between September 2007 and June 2016 at the $20^{\text {th }}$ August Hospital, Ibn Rochd University Medical Center in Casablanca, reported the isolation of a germ in 27 cases $(25 \%)$ : pneumococcus $(12 \%)$, streptococcus $(7 \%)$, gram negative bacilli (4\%), Pseudomonas aeroginosa and Koch bacillus (2\%) [8].

The predominance of pneumococcus in the pleurisy of the child has been reported in several series (58\%) [23,24], (82.9\%) [25], and (75\%) [26]. However, Baranwal, et al. [12] reported a predominance of staphylococcus in India (62\%).

\section{Therapeutic and evolutional aspects}

The management of purulent pleurisies in children continues to be a subject of debate. Some western teams $[26,27]$ have proposed algorithms to facilitate treatment. In our case, we started off with two presumptive broadspectrum antibiotics acting on both aerobic and anaerobic germs, before the microbiology lab results were out, and adjusted à posteriori upon reception of results. Patients also underwent thoracocentesis $(84 \%)$, thoracostomy drainage $(20 \%)$, decortication in case of pachypleuritis $(2.96 \%)$, analgesics/antipyretics (90\%), $\mathrm{O}_{2}$ in case of respiratory distress (37.5\%). Physical therapy was systematic. The most frequently used antibiotics were amoxicilline + clavulanic acid (70\%), ceftriaxone $(35 \%)$, gentamicin $(20 \%)$, and metronidazole $(4 \%)$.

The utilization of fibrinolytics has not yet been incorporated into our clinical practice $[28,29]$. But several authors $[20,21]$ have reported its efficacy in shortening the duration of hospitalization, and the need for surgery.

The mean duration of hospitalization was 17.17 days which was obviously long, but similar to several other authors $[14,30]$.

The most frequently reported complication in the literature is pachypleuritis [27,31]. It was found in $2.96 \%$ of cases in our study. According to a report by Rashna, et al. [32,33] in India, this complication was found in $16.7 \%$ of cases.

There was no case of death in our series as well as that of Zeriouel [23], contrary to reports made by other authors $[8,33]$. Deaths were linked essentially to young age and pleuropulmonary staphylococcal infections [34-37].

\section{Conclusion}

Acute respiratory infections in general, and purulent pleurisies in particular, remain relatively frequent in the context of socio-economic under-development. They occur mainly during cold seasons. Pneumococcus remains the main causal agent in these cases. Given the immediate seriousness of the disease and the several sequellae, which could be disabling, it is preferable to have a simple management algorithm which takes into account our conditions of practice and the therapeutic advancements available on the subject.

\section{References}

1. Ferre A, Dres M, Azarian R (2011) Pleurésies purulentes. Elsevier-Masson SAS Link: https://bit.ly/2ELkniR

2. Joaquin B, Vicenç $F$, Albert $P$ (2013) The increasing incidence of empyema Curr Op in Pulm Med 4: 350-356. Link: https://bit.ly/2HK9AGX

3. Carrie L, Kent $K$, Andrew P (2006) Impact of pneumo-coccal conjugate vaccine on pneumococcal parapneu-monic empyema. Pediatr Infect Dis 25: 250 -254. Link: https://bit.ly/3n4shp2

4. Thiam L (2017) Les pleurésies purulentes de l'enfant :expérience du centre hospitalier national d'enfants Albert Royer de Dakar (SENEGAL). 5. Link: https://bit.ly/2GaOBws

5. Bagalkot PS (2018) A study of empyema thoracis in children. Indianjournal of applied research 8. Link: https://bit.ly/2GfaF94

6. Narayanappa D, Rashmi N, Prasad Na (2013) Clinico-bacteriological Profile and Outcome of Empyema. Indian Pediatr 50: 783-785. Link: https://bit.ly/30m0aYt

7. Khouchilia FZ, Moubachir $H$, Jabri W, Elkhattabi W, Afif $H$ (2017) Profil bactériologiquedes pleurésies purulentes. Revue des Maladies Respiratoires. 34: A109. Link: https://bit.ly/3kUtg96

8. Chez L'enfant KFP (2011) Aspects Epidémio-logiques, Cliniques, Paracliniques, Thérapeutiques et Evolutifs au Centre Hospitalier Universitaire Pédia-trique Charles de Gaulle de Ouagadougou (Burkina Faso). Clinics in Mother and Child Health 8: 16-21.

9. Joon-Ho L, So HK, Jina L, Eun HC, Hoan JL (2012) Diagnosis of pneumococcal empyema using immunochromato-graphic test on pleural fluid and serotype distribution in Korean children. Diagn Microbiol Infect Dis 72: 119-124. Link: https://bit.ly/2Gr9kf5

10. Roxanne E, Anita C, Gwendolyn L, Tanya G (2011) Bac-terial Causes of Empyema in Children, Australia, 2007-2009. Emerg Infect Dis 17: 1839-1845. Link: https://bit.ly/3nemFZo

11. Rashna D (2011) Empyema Thoracis: Analysis of 150 Cases from a Tertiary Care Centre in North East India. Indian J Pediatr 78: 1371-1377. Link: https://bit.ly/36ifnOD

12. Baranwal AK, Singh M, Marwaha RK, Kumar L (2003) Empy-emathoracis: a 10year comparative review of hospital-ized children from south Asia. Arch Dis Child 88: 1009-1014.

13. Lukuni-Massika L, Binda K, Muaka P, Omanga U (1990) Suppurations pleurales chez l'enfant : aspects épidémiologiqueset étiologiques. Med Afr Noire 37: 24 28. Link: https://bit.ly/36hJzc3

14. Ndiaye O, Diack-MbayeA, Ba M, Sylla A, Sow HD, et al. (2000) Pleurésies 
purulentes à staphylocoque doré de l'enfant. Expérience de l'hôpital d'enfants Albert-Royer du CHU de Fann à Dakar Sante 10: 93-96. Link: https://bit.ly/3l3Whzd

15. Weil-Olivier C, Levy C, Marguet C, Sardet A, De La Rocque F (2005) Enquête rétrospective multicentrique sur les pleuropneumopathies infectieuses de l'enfant en France. ArchPediatr 12: 823-826. Link: https://bit.ly/2GclPdB

16. Alao MJ, Sagbo GG, Diakité AA, Ayivi B (2010) Pleurésiechez l'enfant au centre national Hospitalier et Universitaire deCotonou: aspects épidémiologiques, cliniques, paracliniques etthérapeutiques, Mali Med 25: 47-51. Link: https://bit.ly/30gYSOj

17. Atakouma DY, Tatagan AK, Agbere AD, Katchalla-Moustapha B, Gbadoe A, et al (1995) Aspects cliniques,thérapeutiques et évolutifs de la staphylococcie pleuropulmonairedu nourrisson au CHU de Lomé-Tokoin (Togo), MedAfr Noire 42: $260-266$.

18. Ndiaye O, Diack-Mbaye A, Ba M, Sylla A, Sow HD, et al. (2000) Pleurésies purulentes à staphylocoque doré del'enfant. Expérience de l'hôpital d'enfants Albert-Royer du CHUde Fann à Dakar. Sante 10: 93-96. Link: https://bit.ly/33dlolM

19. Garba M, Rabiou S, Kamaye M, Aboubacar S (2015) Profil épidémiologique Et pronostic de la pleurésie purulente chez l'enfant. J Fran Viet Pneu 19: 1-73. Link: https://bit.ly/36kSppK

20. Bagalkot PS (2018) A study of empyema thoracis in children. Indianjournal of applied research 8. Link: https://bit.ly/2GfaF94

21. Narayanappa D, Rashmi N, Prasad NA, Kumar A (2013) ClinicobacteriologicalProfile and Outcome of Empyema. Indian Pediatri 50: 783-785. Link: https://bit.ly/30gZZOr

22. Weil-Olivier C, Levy C, Marguet C, Sardet A, Cohen R, et al. (2005) Enquête rétrospective multicentrique sur les pleuropneumopathies infectieuses de l'enfant en France. Arch Pediatr 12: 823-836. Link: https://bit.ly/2Sa3y46

23. Zeriouel A (2010) Les pleurésies purulentes de l'enfant : À propos de 35 cas Thèse soutenue à Fès en. Link: https://bit.ly/36nz4UH

24. Tzou-Yien L, Kao P, Ching-Chuan L, Ching-Yuang L, Tang RB, et al. (2013) Etiology of empyema thoracis and parapneumonic pleural effusion in Taiwanese children and adolescents younger than 18 years of age. Pediatr Infect Dis J 32: 419-421. Link: https://bit.ly/3n3oKHg

25. Hernandez-Bou S, García-García JJ, Esteva C, Gené A Luaces C, et al. (2009) Pediatric Parapneumonic Pleural Effusion: Epidemiolo-gy, Clinical
Characteristics, and Microbiological Dia-gnosis. Pediatr Pulmonol 44: 1192 1200. Link: https://bit.ly/34fEBdc

26. Tzou-Yien L, Kao P, Ching-Chuan L, Ching-Yuang L, Tang RB, et al. (2013) Etiology of empyema thoracis and parapneumonic pleural effusion in Taiwanese children and adolescents younger than 18 years of age. Pediatr Infect Dis J 32: 419-421. Link: https://bit.ly/3n3oKHg

27. Edward C, John W, Weiya Z, Lucas H, Gregory R (2010) Management of Children With Empyema: Pleural Drainage Is Not Always Necessary. Pediatr Pulmonol 45: 475-480. Link: https://bit.ly/34aP0ab

28. Adam J, Ian M (2005) Management of empyema in children. Pediatr Pulmono 40: 148-156. Link: https://bit.ly/3n4XM28

29. Rahul B, Nick AM (2013) Treatment of Complicated Pleural Effusions in 2013 Clin Chest Med 34: 47-62. Link: https://bit.ly/3il1WPD

30. Fernando M, Diovanni DG, Antonio N, Stefania T, Francesca R, et al. (2000) Treatment of Complicated Pleu-ral Effusion With Intra cavitaryUrokinase in Children. PediatrPulmonol 29: 438-442. Link: https://bit.ly/3jfMSo1

31. Alao MJ, Sagbo GG, Diakité AA, Ayivi B (2010) Pleurésiechez l'enfant au centre national Hospitalier et Universitaire deCotonou: aspects épidémiologiques, cliniques, paracliniques etthérapeutiques, Mali Med, 25: 47-51. Link: https://bit.ly/3n7b8uy

32. Michelle M, Kristin A, Bruce Edmonson M (2014) Treatement trends and outcomes in US hospital stays of children with empyema. Pediatr Infect Dis J 33: 431-436. Link: https://bit.ly/33d2mn5

33. Rashna D (2011) Empyema Thoracis: Analysis of 150 Cases from a Tertiary Care Centre in North East India. Indian J Pediatr 78: 1371-1377. Link: https://bit.ly/36ifnOD

34. Alao MJ, Sagbo GG, Diakité AA, Ayivi B (2010) Pleurésie chez l'enfant au centre national hospitalier et universitaire de Cotonou : aspects épidémiologiques, cliniques, paracliniques, paracliniques et thérapeutiques. Mali Méd 25: 47-51. Link: https://bit.ly/3ioFV2N

35. Blanc P, Dubus JC, Bosdure E, Minodier P (2007) Pleurésies purulentes communautaires de l'enfant. Où en sommes-nous ? ArchPediatr 14: 64-72. Link: https://bit.ly/2Gk5iFp

36. Ranaivoarisoa R, Rasamoelisoa J, Raobijaona H (2000) Prise encharge des pleurésies purulentes de.

37. Sardet A (2000) Les pleurésies. Conduites diagnostique et thérapeutique ArchPediatr 7: 33-38. Link: https://bit.ly/2Go217W

Discover a bigger Impact and Visibility of your article publication with Peertechz Publications

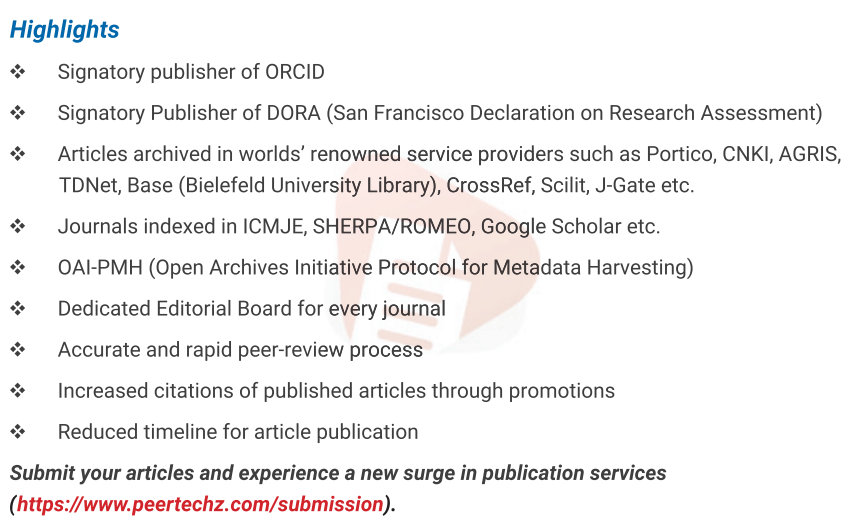

Peertechz journals wishes everlasting success in your every endeavours.

Copyright: ( 2020 Zahra MF, et al. This is an open-access article distributed under the terms of the Creative Commons Attribution License, which permits unrestricted use, distribution, and reproduction in any medium, provided the original author and source are credited. 